\title{
Models for Supporting Mobility as a Service (MaaS) Design
}

\author{
Giuseppe Musolino (D), Corrado Rindone *(D) and Antonino Vitetta
}

\author{
Dipartimento di Ingegneria dell'Informazione, delle Infrastrutture e dell'Energia Sostenibile, \\ Università Mediterranea di Reggio Calabria, Feo di Vito, 89122 Reggio Calabria, Italy; \\ giuseppe.musolino@unirc.it (G.M.); vitetta@unirc.it (A.V.) \\ * Correspondence: corrado.rindone@unirc.it
}

check for updates

Citation: Musolino, G.; Rindone, C.; Vitetta, A. Models for Supporting Mobility as a Service (MaaS) Design. Smart Cities 2022, 5, 206-222. https://doi.org/10.3390/ smartcities5010013

Academic Editors: Anna Visvizi and Giuseppe Guido

Received: 15 December 2021 Accepted: 10 February 2022 Published: 17 February 2022

Publisher's Note: MDPI stays neutral with regard to jurisdictional claims in published maps and institutional affiliations.

Copyright: (C) 2022 by the authors. Licensee MDPI, Basel, Switzerland. This article is an open access article distributed under the terms and conditions of the Creative Commons Attribution (CC BY) license (https:// creativecommons.org/licenses/by/ $4.0 /)$.

\begin{abstract}
Mobility as a Service (MaaS) is the new approach in transportation systems that allows users to use different transport services as a single option, by using digital platforms and with integrated design. In MaaS many actors can be identified: MaaS operators, MaaS companies, MaaS users, citizens, system manager/planner. In order to be able to design the system in an integrated way, it is necessary to identify comprehensive methodologies that make it possible to reach sustainability targets in a context where the decisions to be taken are shared between several operators and affect users and citizens. In this paper, the methods to be adopted for the design of an integrated transport service system have been studied. The main aim of this paper concerns the specification of transport system models for estimating the effects of decision-makers' actions on MaaS. The consolidated design methodologies of transport networks have been extended in the context of the MaaS. The paper reports a methodology that can be used and describes the main models to be used, which derive from consolidated specifications in the field of transport systems engineering. The methodologies have to be integrated into Intelligent and Communication Technology systems to build the Intelligent Transport System in the MaaS environment.
\end{abstract}

Keywords: sustainable mobility; network design problem; mobility as a services; decision-making

\section{Introduction}

There is a large corpus of literature on technologies, methods and models aimed to increase sustainable mobility. Sustainability, as general issue, is a challenge at global level. In the 2030 Agenda for Sustainable Development [1,2], sustainable mobility is one of the pillars to consider for achieving the Sustainable Development Goals (SDGs).

The transport system design, and more in general, the transportation planning process aims to find transport solutions, in terms of infrastructure and services, that allows people and business to realise main ordinary activities, such as jobs, education, leisure [3]. Traditionally, Transport Systems Models (TSMs) support transport planning and design processes in order to find the solutions and estimate potential effects. In recent years, Information and Communication Technologies (ICTs) allowed to providing new types of mobility services such as car-sharing and ride-sourcing [4]. Moreover, ICTs enable further insight of transport system, providing personalised solutions based on travel user's needs. TSMs and ICTs and constitute the main elements of an Intelligent Transport System (ITS). This is one of the main characteristics of the Mobility as a Service (MaaS), that allows users to use different transport services as a single option, by using digital platforms with the transport services designed with an integrated method and considered as an unicum. Nevertheless, beyond the support of ICT solutions, the available transport options inside a MaaS framework, have to be designed adopting consolidated transport methodologies, extended and revised for the specific case. MaaS cannot be considered a mere integration of ICT platforms and single optimized transport services, or a new alternative service offered to transport users. MaaS generates from the integration of transport services and ICT solu- 
tions. One of the main problems of MaaS platforms is related to modelling users' behaviour as well as effects of decision-makers' actions (e.g., transport services characteristics) [5].

The general objective of the paper is to explore how consolidated methods on transport services design could be updated and revised in order to provide to planners and operators for a support for the service planning process inside a MaaS framework.

The paper mainly deals with the following two research topics:

- MaaS, comprehending literature on new approaches to mobility evolving from the traditional concept of transport services, based on services provided with a single transport mode, to the concept of MaaS, based on consumer mobility needs provided by an integration of services that allow door-to-door trips without the need to own a private vehicle [6]; MaaS concept is strictly connected to ICT;

- Methods for transport services design, that allow planners to reach an equilibrium between the mobility needs (demand) and transport services (supply) in an integrated way, in presence of Intelligent Transportation Systems (ITSs) [7-9]. This topic comprehends literature on:

- Network Design Problem (NDP), including methods (models and procedures) to design transport infrastructures and its topology;

- Vehicle Routing Problem (VRP), including methods (models and procedures) to design transport and mobility services;

- TSMs, including methods (models and procedures) that support NDP and VRP for demand, supply and demand-supply interaction.

Each class of methods, with their specific potentialities, support different actors (i.e., MaaS operators, system manager/planner) involved in the design and management of a MaaS.

In the authors' knowledge, the evaluation of potential contributes of TSMs to plan MaaS services started to be studied recently, and it requires further research to be consolidated and integrated (a state of the art is reported in Section 2). There are some seminal papers in this specific area. Kamargianni et al. [10] proposed an integrated transport modelling framework to simulate the effects of MaaS inside the transport system and incorporated MaaS-oriented features into an integrated supply and demand activity-based model.

The main objective of the paper is to investigate the way to incorporate MaaS concepts into transport supply models, in order to adopt consolidated design methods to design MaaS services for reaching sustainability goals. The main issue concerns the resources optimization in order to guarantee the new mobility needs of people, or, in other words, to design a Sustainable MaaS (S-MaaS). In particular, the paper proposes a supply design methodology aimed to optimize mobility services for people in order to minimize resources. As far as concerns S-MaaS, a digital platform is necessary but not sufficient to reach the integration of services. TSMs support ex-ante evaluations of potential effects produced by decision-makers' actions. TSMs also support ex-post evaluations in providing estimated data that could cover the lack of observed data.

The novelties of this paper are reported in the following.

- The investigation of methods, models and (energy and ICT) technologies inside a framework to support the MaaS policies definition, constituted by transport facilities and services, optimising the use of resources in presence of a ITS (Section 3).

- The proposal of a design model in order to support system managers and/or planners in the design of an integrated transport service inside Maas (Section 4)

- The specification of the main variables and constraints of the proposed design model to be adopted in MaaS context (Section 5).

The following part of paper is subdivided into four sections. Section 2 reports the state of the art concerning the two topics of the paper: MaaS and methods for transport services design. Section 3 illustrates the proposed framework for supporting MaaS policies definition. Section 4 reports an optimization model that can be adopted for services design in a MaaS context. Section 5 reports a specification of the main components (variables, objectives and constraints) of the optimization model to support system manager and/or 
planner in the design of sustainable MaaS services. The last section reports the conclusions and the research perspectives.

\section{State of the Art}

The section presents the literature review concerning the two main elements considered in the paper: MaaS and design methods of transport facilities and services.

\subsection{Mobility as a Service}

"MaaS is a user-centric, intelligent mobility management and distribution system, in which an integrator-the MaaS Operator-brings together offerings of multiple mobility service providers and provides end-users access to them through a digital interface, allowing them to seamlessly plan and pay for mobility" [11].

The MaaS concept was firstly introduced by Hietanen [12]. According to him, MaaS is an ecosystem, where the demand of mobility of users and the supply of bundled infrastructures and services interact in a digital interface powered by a service provider.

The successive debate focused on the main approaches of MaaS (see [13] for a review). According to Holmberg et al. [14], MaaS includes several transport services, from peer-topeer services to services that attempt to optimize the connection between individual cars and public transport. Kamargianni et al. [10] proposed that intermodal planning, booking and payment functionalities, as well as multiple transport modes and mobility packages, are important components of MaaS.

Some authors emphasized the user-centric vision of MaaS [15]. According to this, MaaS ensures the possibility to concentrate the booking and payment operations and the possibility to offer mobility services tailored on user's preferences [16,17]. Some recent works underline the need to develop frameworks for analyzing MaaS policy programs [18].

Several authors $[12,19,20]$ highlighted the key role of ICT and Internet because they allow to collect, process, and transmit information to users; and to integrate information among users, providers, and services.

Other authors consider sustainability as the goal of MaaS. According to Giesecke et al. [20], MaaS enables to modify transport users' behaviours towards a sustainable goal. According to König et al. [21], MaaS offers tailored mobility solutions to transport users with the goal of achieving a more sustainable transport. By implementing and delivering innovative services as MaaS, it could be possible to enhance accessibility and equity through a shift from ownership-based to access-based transportation [22,23].

\subsection{Design Methods for Transport Facilities and Services (NDP and VRP)}

Two main design methods (NDP and VRP) can be identified to support the services design inside MaaS, as reported in the next sub-sections.

The service design has to be supported by the specification-calibration-validation of a demand model, according to the consolidated methodologies reported in [24,25]. Travel demand models are estimated and applied in a MaaS context in recent papers $[10,26,27]$. Travel demand models are relevant but they are out of the scope of this paper.

\subsubsection{Network Design Problem (NDP)}

The NDP refers to the optimal design of road or transit network in terms of topology and capacity. NDP can be classified according to: the variables type (continuous or discrete or mixed), the mode (road or transit or mixed).

Examples of discrete variables are the lane allocation in road systems or the route in the transit systems; examples of continuous variables are the junctions' regulation in road systems or the frequencies in transit systems.

Road Network

In the discrete case the first approaches for links allocation are proposed by Billheimer and Gray [28], Chen and Alfa [29] and Zhou et al. [30]. 
In the continuous case, two sub-cases arise [31,32]: no path choice model and isolated junctions (some of the main initial papers are [33-35] or interacted junctions (some of the main initial papers are [36-39]; path choice model and isolated junctions (some of the main initial papers are $[35,39,40]$ or isolated junctions (some of the main initial papers are $[36,41]$. In mixed case some heuristics are proposed in [31] and a procedure for solutions selection is proposed in Russo and Vitetta [42].

\section{Transit Network}

Russo [43] presented a method for frequencies design; Guihaireab and Hao [44] presented an extended review concerning the design and the scheduling of the transit network for supporting the strategic and tactical steps of transit planning. Bourbonnais et al. [45] proposed a transit network design integrating road supply and travel demand.

Huang et al. [46] propose a multimodal transit network framework for the design of rail and bus services based on the concept of MaaS.

\subsubsection{Vehicle Routing Problem (VRP)}

The VRP refers to the best design of the route followed by passenger or freight vehicles when more than two points have to be visited. The VRP has been extensively studied in literature (for a detailed state-of-the-art see [47-49]. The solution approach is based on two approaches: exact and heuristic. In the exact approach two methods are proposed: lagrangian relaxations [50,51] and Dantzig-Wolfe decomposition [52-54]. In the heuristics approach many heuristics procedures are proposed: genetic [55]; parallel genetic [56]; tabu search [57,58]; simulating annealing [59,60].

With the introduction of electric and hybrid vehicles the VRP was reformulated for considering the new open problems connected to sustainability theme [61]: battery recharge aspects [62]; mixed routing and recharge location points [63]; battery recharge and vehicle load [64]; policy [65].

\subsection{Research Contribution}

Great attention received the development of ICT solutions inside the MaaS frameworks. However, the evaluation of potential contributes of TSMs to plan and design MaaS services started to be studied recently. There are some seminal papers in this specific area (see [10]), which propose an integrated transport modelling framework to simulate the effects of MaaS inside the transport system and attempt to incorporate MaaS-oriented features into an integrated supply and demand activity-based model.

In the author's opinion, the above one is an open research area where a specific studies and analyses are necessary to incorporate MaaS concepts into transport supply models, in order to adopt consolidated integrated design methods for S-MaaS services for reaching sustainability goals.

This paper attempts to fill the aforementioned gaps by developing a framework which explicitly considers and integrates NDP and VRP methodologies, presented in the Section 2.2. The methods support actors to assume their decisions.

The main issue of the framework concerns the resources optimization in order to guarantee the new mobility needs of people, or, in other words, to design a S-MaaS.

\section{Design Methods for Supporting MaaS Policies Definition}

MaaS policies definition require the support of transport networks design methods. The design methods aim to improve the level of service, promoting the optimization of economic, social and environmental sustainability objectives. According to the authors, the methods are necessary for supporting S-MaaS design.

To pursue sustainability objectives for users, citizen and managers, it is necessary to assume decisions concerning transport system elements. The decisions are translated into control variable. 
The control variables for the generation of an optimal network configuration concern the use of road areas (e.g., pedestrian, parking), the allocation of road lanes for vehicles, the regulation at road junctions, the services frequencies and routes, pricing (e.g., parking fees, road pricing). The constraints refer to regulatory, technical and behavioral components that affect users' behaviour (simulated by means of travel demand models).

The designed interventions belong to two categories: prescriptive and non-prescriptive. Examples of prescriptive intervention are regulation of junctions, directions, tolls. Example of non-prescriptive intervention is the information to users.

\subsection{Problems}

The MaaS policies definition implies different problems. The main problem concerns the trade-off among different points of view and the effects of the decisions generally are not additive and/or the effects have the same sign.

The MaaS policies definition is strictly connected to decision-making process in transport system, involving three main components:

(i) involved actors, including different classes of public and private decision makers and users;

(ii) evaluation methods, including models and procedures that support decision makers;

(iii) ICT tools, including technologies for monitoring and data-storage, info-mobility, trip-planners and payment methods.

(iv) The number of actors involved in the design process is different between traditional services and MaaS.

Three components may be identified in traditional services:

- Users,

- Citizens,

- Public Transport Authorities and Mobility Service Providers.

Four components may be identified in MaaS [6]:

- MaaS Platform,

- MaaS Operator,

- public or private or mix, and

- MaaS Users.

Five classes of components/actors are identified in this paper:

- MaaS Operator (MO),

- MaaS Companies (MCs),

- MasS Users (MUs),

- $\quad$ Citizens (C),

- $\quad$ System Manager/planner (SM).

Decision-makers require specific evaluation methods for supporting their decisions. In particular, TSMs, NDP, and VRP allow decision-makers to estimate potential effects produced by the implementation of their decisions in long and/or short-term scenarios. Traditionally, TSMs and design methodologies are used by a single actor in order to estimate effects of their decisions concerning a component of the system. In a S-MaaS context, available methods play a relevant role in order to support shared decisions that increase the capability of:

- $\quad$ supply management:

- fleet management operations of the MaaS Companies (MC),

- design of transport infrastructures (linear and punctual) and integrated mobility services,

- demand management; design and implementation of strategies to drive user's behavior (incentives and disincentives), 
- $\quad$ system (demand/supply) management: design of MaaS product, multimodal tripplanning, dynamic pricing and incentives.

The decisions regard transport system elements and their features that influence user's behaviour. Modification of transport system's elements could produce direct and indirect effects, in relation to the actor's objectives (outcomes and goals).

ICT tools have two different roles:

- monitor and store information and data useful to design the characteristics of the integrated mobility services;

- $\quad$ provide information to users about available transport options tailored on their specific mobility needs.

Information are useful in an accountability context to inform citizens about ex-ante and ex-post evaluation related to sustainable mobility.

\subsection{Methods}

The section presents a framework for S-MaaS policies definition in presence of ITS.

Modelled and observed effects are the core of an Intelligent Transport System (ITS) that supports the decision process, composed of three sub-processes (Figure 1):

\section{a.) Decision making}

$\overbrace{\begin{array}{l}\text { b.) Effects of decisions } \\ \text { (modelled by DSS) }\end{array}}^{\text {Intelligent Transport System }}$

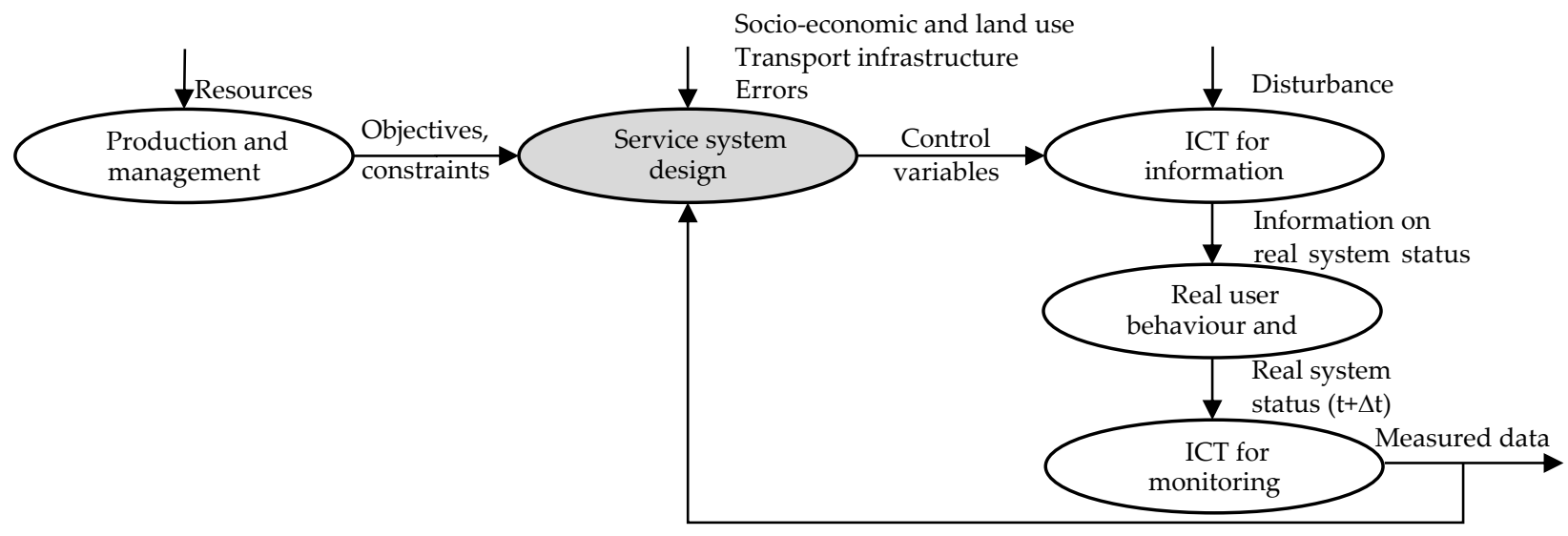

Figure 1. The framework to support S-MaaS policies definition.

a. Decision Making, a decision-making process where resources are needed to produce and manage transport infrastructures and services; the process defines objectives and constraints for the planning, programming and realisation phases;

b. Effects of decisions (modelled by DSS), a simulation process where potential effects produced by decisions on transport system are estimated; a set of models, fed by measured data, simulate user' behaviour and travel choices in relation to planned transport infrastructures and services; models constitute the core of a Decision Support System (DSS) that support definition of control strategies designed in order to reach objectives respecting constraints (this process is reported in Section 4);

c. Effects of decisions (measured by ICT), a measurement process where real effects produced by decisions on transport system are measured; a set of Information and Communication.

Technologies (ICT) perform two different activities:

- ICT provide information on real system status at the instant $t$; the system is an implementation of control strategies defined in the sub process b.) and it includes available transport infrastructures and services for people and goods 
trips; transport users and its behaviours generate a new status of real system at the instant $\mathrm{t}+\Delta \mathrm{t}$;

- ICT measure effects on real system in the status registered at the instant $t+\Delta t$; the system results from real supply-demand interactions.

The integration between the two sub-process b. and c. constitutes an Intelligent Transport System (ITS).

\section{Service System Design Models}

The description of the components, of the inputs and of the outputs of the proposed method is reported in Figure 2. The inputs are the objectives connected to the three sustainability components: economic, social, environment. The outputs are the optimal services for passengers and freight (control or design variables).
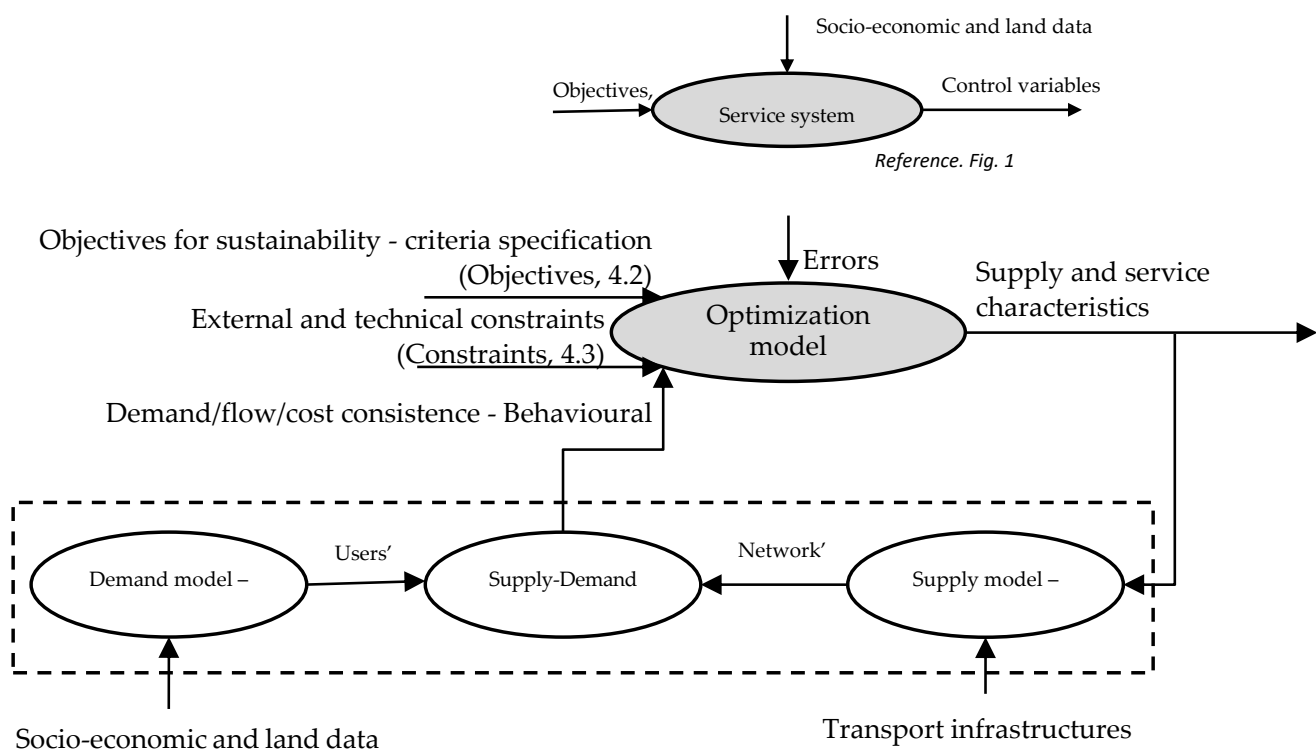

Figure 2. Transport System Models for services design (controller).

An optimization model ("what-to" approach) generates the best configuration to apply, design and manage the supply system in order to reach the defined objectives. The optimization approach is different from the simulation (or "what-if") approach; where some a-priori supply configurations are simulated and compared and the best configuration is chosen.

Some constraints have to be defined in the optimization procedure. They are external (i.e., rules, laws), technical (i.e., budget, vehicle type) and behavioral (i.e., passengers, freight operators, manager choice). The behavioral constraints are non-linear and require a more extended specific section for their description.

\subsection{Control Variables}

The methodology allows the design of the optimal configuration (respect the defined objectives, Section 4.2) of the transport services inside a S-MaaS.

It is worth noting that the route for passenger vehicles cannot be designed considering that it can be chosen with passenger individual decision with pre or en-route behaviour (behaviour constraint, Section 4.4).

All the decision variables, from a math point of view, can be assumed reported in a vector $\mathbf{y}$ of the control variables. Each variable is reported with a specific value that represents the specific service configuration (i.e.,: the size of parking area in term of number of parking space; the route for freight vehicles is reported with the node sequence). 
Each control variable has a feasible set. Considering the vector $\mathbf{y}$ of the control variables, it can assume values in a defined and fixed feasible set $\psi_{c v}$ (i.e., the number of parking space must be positive and integer and cannot be higher than a fixed number obtained from the availability areas defined for parking):

$$
\mathbf{y} \in \psi_{c v}
$$

\subsection{Objectives}

The sustainability has many components, but they are generally grouped in three classes: economic, social and environment. The problem cannot be specified and solved with in mono-criterion approaches. Many objectives, criteria and goals are defined and they may be divergent in relation to the control variables some of them could increase and some of them decrease with the variation of each control variables. A multi-criteria optimization problem has to be formulated and more than one objective has to be specified.

The objectives are reported the vector of objective functions:

$$
\varphi(\mathbf{y}, \mathbf{f})
$$

with:

- $\quad \mathbf{y}$, vector of control variables;

- $\quad \mathbf{f}$, vector of internal variables, named traffic flows or the behavioral constraints (Section 4.4).

The external parameters are considered as fixed in this problem (i.e., socio economic data) and for this reason not explicitly reported in Equation (2) for simplicity sake.

The specification of the objectives is relative to the specific problem studied. In broad terms, they allow to evaluating economic (i.e., travel time, monetary costs for users and system manager, level of service, energy consumption), social (i.e., accessibility, incidents) and environmental (i.e., pollutants emissions at well to tank and tank to well levels) objectives.

The optimal solution $\mathbf{y}^{*}$ is obtained with a constrained optimization problem (the constraints are reported in Sections 4.3 and 4.4), where the minimum of the objective function $\varphi(\mathbf{y}, \mathbf{f})$ is obtained respect the variation of the control variable $\mathbf{y}$ (it is equivalent to say that $\mathbf{y}^{*}$ is the value of the vector $\mathbf{y}$ in the minimum point of the objective function $\varphi(\mathbf{y}, \mathbf{f}))$ :

$$
\mathrm{y}^{*} \text { obtained from Minimum } \mathrm{y} \varphi(\mathbf{y}, \mathbf{f})
$$

Therefore, the solution to the problem occurs through solution techniques that consider more objectives / criteria (e.g., multi-criteria methods, DEA). The solution procedure, for real size system and real time solutions, requires heuristics methods, as reported in Section 2.

\subsection{External and Technical Constraints}

External (E) and Technical (T) constraints represent the feasible set of the variables that are not managed and designed in the problem. Some (not exhaustive) examples of these constraints are: rule, law and procedure to be followed; type of vehicles (i.e., fully electric vehicles, recharge time, recharge energy); number of available vehicles; monetary budget; freight class restrictions, e.g., dangerous good; territorial characteristics; land use data; touristic attraction; available areas of parking area and freight distribution center location.

The $\mathrm{E}$ and $\mathrm{T}$ constraints can be formulated in different ways. They are often linear respect to the control (y) and the internal (f) variables.

From a mathematical point of view, $\mathbf{y}$ and $\mathbf{f}$ belong to two feasible sets, respectively $\psi_{E T y}$ and $\psi_{E T f}$ :

$$
\begin{aligned}
& \mathbf{y} \in \psi_{E T y} \\
& \mathbf{f} \in \psi_{E T f}
\end{aligned}
$$




\subsection{Behavioral Constraints}

Constraints related to supply, demand and supply/demand transport system components are identified:

- $\quad$ supply: a network approach is adopted. At each elements of the graph representing network's topology (nodes, links, performance) it is possible to associate a user cost (Section 4.4.1);

- demand, constraints regard each level of travel choice (origin, destination, ... ) (Section 4.4.2);

- demand/supply, constraints represent interactions among users and real operators (Section 4.4.3).

A non-linear constraint is defined for internal variable $\mathbf{f}$, relative to users' behavior and to strategy adopted for the system management. Users maximize the utility adopting a subjective utility maximization; system manager minimize the management costs. Users and system manager could adopt also strategy for economic, social and environmental optimization. This constraint is not linear and requires the definition of a supply, demand and demand/flow / cost consistency sub-models, reported in the next sections.

\subsubsection{Supply}

The transport supply defines the performances resulting from users and from infrastructures and services. The most consolidated modelling approach is based on topological representation, or network model.

The supply model is defined with three equations [25]:

$$
\begin{gathered}
f=\Delta h \\
g=\Delta^{\prime} c \\
c=\Gamma(f, y)
\end{gathered}
$$

with

c and $\mathbf{g}$ respectively the generalized link and path costs vectors, including monetary cost, travel time, energy consumption;

$\mathbf{f}$ and $\mathbf{h}$ respectively the link and path flows vectors;

$\Gamma$ the link-cost flow functions vector;

$\Delta$ the link path incidence matrix.

\subsubsection{Demand}

The travel demand defines users' choices resulting from activities and infrastructure and service performances. The existing models have different theoretical backgrounds for passengers and freight.

The demand model is defined with thee equations [25]:

$$
\begin{gathered}
P(\mathrm{~g}, \mathrm{y}) \\
d(\mathrm{~g}, \mathrm{y}) \\
\mathrm{h}=P(\mathrm{~g}, \mathrm{y}) d(\mathrm{~g}, \mathrm{y})
\end{gathered}
$$

with

$\boldsymbol{P}(\mathbf{g}, \mathbf{y})$ the demand-OD (Origin-Destination) functions matrix for path(route) choice probability;

$d(\mathbf{g}, \mathbf{y})$ the demand-OD (Origin-Destination) vector for emission, distribution, modal split values. 


\subsubsection{Demand/Flow/Cost Consistency (Assignment Model)}

According to the supply and demand models defined in the two previous sub-sections, the Demand/Flow/Cost consistency model can be defined. The assignment model reproduces the mutual interaction between users' choices and infrastructure and service performances.

Combining Equations (6) and (9)-(11), the following may be obtained:

$$
\mathrm{f}=\Delta P(\mathrm{~g}, \mathrm{y}) d(\mathrm{~g}, \mathrm{y})
$$

By considering the Equations (7) and (8), the dependency of $\boldsymbol{P}$ and $\boldsymbol{d}$ from the link flow and cost vectors may be expressed:

$$
\left.\mathbf{f}=\Delta P\left(\Delta^{\prime} \Gamma(\mathbf{f}, \mathrm{y}), \mathrm{y}\right) d\left(\Delta^{\prime} \Gamma \mathrm{f}, \mathrm{y}\right), \mathrm{y}\right)
$$

The Equation (13) defines the static dependency of the flow vector, $\mathbf{f}$, from the link cost function $\Gamma$ (that depends on $\mathbf{f}$ and $\mathbf{y}$ ), from the control variable $\boldsymbol{y}$, and from some independent values and functions of describing the transport system: $\boldsymbol{\Delta}, \boldsymbol{P}, \boldsymbol{\Gamma}, \boldsymbol{d}$.

After defining a loading function $\psi_{f}$, Equation (13) can be reported in a compact form:

$$
\mathbf{f}=\psi_{f}(\mathbf{f}, \mathbf{y})
$$

The flow vector has to be not negative and have to respect Equation (6). In a compact form it can be reported that have to belong to the feasible set $\psi_{B f}$ :

$$
\mathbf{f} \in \psi_{B f}
$$

In a dynamic context, the behavioural constraint should consider the temporal of the evolution demand/flow/cost consistency. Two approaches can be adopted: within-day and/or day-to-day models [66], respectively for intra-period or period-to-period variations. The study of these models is out of the scope of this paper, considering that the general formulation of Equation (14) does not change.

\subsection{Optimization Model}

The problem reported in the previous sections can be solved applying an optimization model that considers (respectively) the models represented by Equations (1), (3)-(5), (14) and (15). The optimization model can be specified as:

$$
\left\{\begin{array}{c}
\mathbf{y}^{*} \text { obtained from } \\
\text { Minimum }_{\mathbf{y}} \boldsymbol{\varphi}(\mathbf{y}, \mathbf{f}) \\
\text { subject to } \\
\mathbf{y} \in \boldsymbol{\Psi}_{c v} \\
\mathbf{y} \in \boldsymbol{\Psi}_{E T v} \\
\mathbf{f} \in \boldsymbol{\Psi}_{E T f} \\
\mathbf{f} \in \boldsymbol{\Psi}_{f}(\mathbf{f}, \mathbf{y}) \\
\mathbf{f} \in \boldsymbol{\Psi}_{B f}
\end{array}\right.
$$

The optimization model (16) is formulated with a nonlinear objective function subject to linear and nonlinear constraints. The control variables are mixed continuous and discrete.

\section{Model Specification in a MaaS Context}

This section reports the specification of the proposed design model in a MasS context, identifying the variables and the constraints.

Each actor involved in MaaS implementation requires a sub set of methods and ICT tools for performing their activities (Table 1). Table 1 reports only the main interactions, because weak interactions are in every case active. 
Table 1. Main interaction between actors, evaluation methods and ICT.

\begin{tabular}{|c|c|c|c|c|c|c|c|c|c|}
\hline \multirow[b]{2}{*}{$\begin{array}{l}\text { (i) } \\
\text { Actor * }\end{array}$} & \multicolumn{5}{|c|}{ (ii) Methods (Models and Procedures) } & \multicolumn{4}{|c|}{ (iii) ICT Tools } \\
\hline & $\begin{array}{c}\text { Temporal } \\
\text { Scenarios } \\
\text { (Long/Short } \\
\text { Term) }\end{array}$ & $\begin{array}{c}\text { Supply } \\
\text { Management }\end{array}$ & $\begin{array}{l}\text { Supply } \\
\text { Design }\end{array}$ & $\begin{array}{c}\text { Demand } \\
\text { Management }\end{array}$ & $\begin{array}{c}\text { Demand/Supply } \\
\text { Management }\end{array}$ & $\begin{array}{l}\text { Monitoring } \\
\text { and Storage }\end{array}$ & $\begin{array}{c}\text { Info- } \\
\text { Mobility }\end{array}$ & $\begin{array}{c}\text { Trip } \\
\text { Planner }\end{array}$ & $\begin{array}{l}\text { Payment } \\
\text { Methods }\end{array}$ \\
\hline $\mathrm{MO}$ & $x$ & & $x$ & $X$ & $X$ & $X$ & $X$ & $X$ & $X$ \\
\hline MCs & $x$ & $x$ & $x$ & & $X$ & $x$ & $x$ & $x$ & $X$ \\
\hline MUs & $x$ & & & $x$ & $x$ & $x$ & $X$ & $x$ & $X$ \\
\hline $\mathrm{C}$ & $x$ & & & $x$ & $X$ & $X$ & & & \\
\hline SM & $x$ & & $X$ & $x$ & $x$ & $x$ & & $X$ & $X$ \\
\hline
\end{tabular}

* MO: MaaS Operator; MCs: MaaS Companies; MUs: MasS Users; C: Citizen; SM: System Manager/planner.

Evaluation methods support the actors in relation to a specific design's problem related to the individual or collective passenger mobility and the temporal future scenario at short and/or long term. In relation to each mobility component, temporal scenario and decisions actors. Table 2 reports the transport system element that can be designed with the support of the evaluation methods indicated in Table 1. Each element, and relative quantitative attributes and features, constitutes the decision's object of the actors. The decisions, after their implementation, have an expected effect in the short and/or long term.

Table 2. Evaluation methods (ii) for transport system component design in relation to passenger mobility.

\begin{tabular}{|c|c|c|c|c|c|}
\hline & $\begin{array}{l}\text { Temporal } \\
\text { Scenario }\end{array}$ & $\begin{array}{c}\text { Supply } \\
\text { Management }\end{array}$ & $\begin{array}{l}\text { Supply } \\
\text { Design }\end{array}$ & $\begin{array}{c}\text { Demand } \\
\text { Management }\end{array}$ & $\begin{array}{c}\text { System } \\
\text { (Demand/Supply) } \\
\text { Management }\end{array}$ \\
\hline $\begin{array}{l}\text { Individual mobility } \\
\text { (as passenger) }\end{array}$ & $\begin{array}{l}\text { short term } \\
\text { long term }\end{array}$ & $\begin{array}{c}\text { vehicle } \\
\text { infrastructure }\end{array}$ & $\begin{array}{c}\text { route, zone } \\
\text { vehicle, infrastructure }\end{array}$ & $\begin{array}{l}\text { zone, fares } \\
\text { parking }\end{array}$ & $\begin{array}{c}\text { paths, routes, fares } \\
\text { infrastructure }\end{array}$ \\
\hline $\begin{array}{l}\text { Individual mobility } \\
\text { (as driver) }\end{array}$ & $\begin{array}{l}\text { short term } \\
\text { long term }\end{array}$ & $\begin{array}{l}\text { intersection } \\
\text { infrastructure }\end{array}$ & $\begin{array}{l}\text { paths, routes, } \\
\text { intersection, zone } \\
\text { infrastructure }\end{array}$ & $\begin{array}{c}\text { zone, node, parking } \\
\text { zone }\end{array}$ & $\begin{array}{c}\text { paths, routes, fares } \\
\text { infrastructure }\end{array}$ \\
\hline Collective mobility & $\begin{array}{l}\text { short term } \\
\text { long term }\end{array}$ & $\begin{array}{c}\text { timetable } \\
\text { vehicle, } \\
\text { infrastructure }\end{array}$ & $\begin{array}{l}\text { stops, routes, timetable } \\
\text { vehicle, infrastructure }\end{array}$ & $\begin{array}{l}\text { timetable, fare } \\
\text { vehicle, } \\
\text { infrastructure }\end{array}$ & $\begin{array}{c}\text { paths, routes, } \\
\text { timetable, fares } \\
\text { vehicle, } \\
\text { infrastructure }\end{array}$ \\
\hline
\end{tabular}

\subsection{Control Variables}

In relation to mobility of people in MaaS context, the main control variables represent the transport characteristics in terms of infrastructures (e.g., bus stop location, the parking area location and size) and services (transit routes, timetables, vehicles, ... ) and it can be specified in relation to:

- collective transport services (Table 3);

- individual transport services, by distinguishing the case when user is a passenger (Table $4 a$ ) or a driver (Table 4 b).

For each variable there is an example with the indication of unit of measure (UoM). Each variable represents an element of designed transport network (stops, links, paths, routes, vehicles, timetable). Variables can be: discrete, if they represent for instance, topological design elements: continuous, if they represent, for instance, temporal or spatial design characteristics. In every case, it is necessary to operate a selection among the set of variables, in order to represent the designed transport system element unequivocally. For instance, it is possible to quantify the vehicle number in a transit line or the temporal interval between two successive transit runs. 
Table 3. Main control variables: collective services.

\begin{tabular}{|c|c|c|c|c|c|c|}
\hline Name & Specification & UoM & Type * & Graph Element * & $\begin{array}{c}\text { Involved } \\
\text { Actors * }\end{array}$ & Example \\
\hline \multirow{3}{*}{ Infrastructures } & Localization & Long/Lat & $\mathrm{C}$ & $\mathrm{L}$ & \multirow{3}{*}{$\mathrm{R}$} & Spatial coverage \\
\hline & Quantity & Length & $\mathrm{C}$ & $\mathrm{L}$ & & Physical extension \\
\hline & Features & $\operatorname{Binary}(0 / 1)$ & $\mathrm{D}$ & $\mathrm{L} / \mathrm{N}$ & & Road/urban rail \\
\hline \multirow{2}{*}{ Stops } & Localization & Long/Lat & $\mathrm{C}$ & $\mathrm{N}$ & \multirow{2}{*}{$\mathrm{U} / \mathrm{R}$} & Bus stops location \\
\hline & Services & Binary $(0 / 1)$ & $\mathrm{D}$ & $\mathrm{N}$ & & Express Bus, Tram, Taxy \\
\hline \multirow[b]{2}{*}{ Routes } & Paths & Binary $(0 / 1)$ & $\mathrm{D}$ & $\mathrm{L}$ & \multirow[b]{2}{*}{$\mathrm{U} / \mathrm{R}$} & Link sequence between stops \\
\hline & Sequence of paths & Binary $(0 / 1)$ & $\mathrm{D}$ & $\mathrm{L}$ & & Path sequence \\
\hline \multirow{3}{*}{ Vehicle } & Capacity & Seats/vehicle & $\mathrm{C}$ & $\mathrm{P}$ & \multirow{3}{*}{$\mathrm{U} / \mathrm{R}$} & 50 seats/vehicle \\
\hline & & & & & & Air condition, \\
\hline & Features & Binary $(0 / 1)$ & $\mathrm{D}$ & $\mathrm{P}$ & & Zero emission \\
\hline \multirow{2}{*}{ Timetable } & Frequencies & runs $/ \mathrm{h}$ & $\mathrm{C}$ & $\mathrm{L}$ & \multirow{2}{*}{$\mathrm{U} / \mathrm{R}$} & 12 runs $/ \mathrm{h}$ \\
\hline & Schedule & hh:mm & $\mathrm{C}$ & $\mathrm{L}$ & & Arrival time 08:21 \\
\hline Fares & $\begin{array}{c}\text { Pay as you go } \\
\text { Bundle }\end{array}$ & $\begin{array}{c}€ / \mathrm{h} \\
€ / \text { month }\end{array}$ & $\mathrm{C}$ & $\begin{array}{c}\mathrm{L} / \mathrm{N} \\
\mathrm{S}\end{array}$ & $\mathrm{U} / \mathrm{R}$ & $\begin{array}{c}1 € / \mathrm{h} \\
30 € / \text { month }\end{array}$ \\
\hline
\end{tabular}

* C: Continuous; D: Discrete; N: Nodes; L: Links; S: System; P: Performances; U: Users; R: Real operators.

Table 4. (a) Main control variables: individual services as passenger. (b) Main control variables: individual services as driver.

\begin{tabular}{|c|c|c|c|c|c|c|}
\hline \multicolumn{7}{|c|}{ (a) } \\
\hline Name & Specification & UdM & Type * & $\begin{array}{l}\text { Graph } \\
\text { Element * }\end{array}$ & $\begin{array}{l}\text { Involved } \\
\text { Actors * }\end{array}$ & Example \\
\hline & Localization & Long/Lat & $\mathrm{C}$ & $\mathrm{L}$ & & Spatial coverage \\
\hline Infrastructures & Quantity & Length & $\mathrm{C}$ & $\mathrm{L}$ & $\mathrm{R}$ & Physical extension \\
\hline & Features & Binary $(0 / 1)$ & $\mathrm{D}$ & $\mathrm{L} / \mathrm{N}$ & & Smart road \\
\hline \multirow{2}{*}{ Routes } & Paths & Binary $(0 / 1)$ & $\mathrm{D}$ & $\mathrm{L}$ & \multirow{2}{*}{$\mathrm{U} / \mathrm{R}$} & Link sequence (between two \\
\hline & Sequence of paths & Binary $(0 / 1)$ & $\mathrm{D}$ & $\mathrm{L}$ & & Path sequence \\
\hline \multirow{2}{*}{ Vehicle } & Capacity & Seats/vehicle & $\mathrm{C}$ & $\mathrm{P}$ & \multirow{2}{*}{$\mathrm{U} / \mathrm{R}$} & 4 seats/vehicle \\
\hline & Features & Binary $(0 / 1)$ & $\mathrm{D}$ & $\mathrm{P}$ & & Air condition, Zero emission \\
\hline \multirow{3}{*}{ Zone } & Boundaries & Long/Lat & $\mathrm{C}$ & $\mathrm{N} / \mathrm{L}$ & \multirow{3}{*}{$\mathrm{U} / \mathrm{R}$} & Low Emission Zone \\
\hline & Authorized & Binary $(0 / 1)$ & $\mathrm{D}$ & $\mathrm{L}$ & & Low Emission Vehicles \\
\hline & Rates & $€ / \mathrm{h}$ & C & S & & $5 € / h$ \\
\hline \multirow[t]{2}{*}{ Fares } & $\begin{array}{l}\text { Pay as you go } \\
\text { Bundle }\end{array}$ & $\begin{array}{c}€ / \mathrm{h} \\
€ / \text { month }\end{array}$ & $\mathrm{C}$ & $\begin{array}{l}\mathrm{L} / \mathrm{N} \\
\mathrm{S}\end{array}$ & \multirow[t]{2}{*}{$\mathrm{U} / \mathrm{R}$} & $\begin{array}{c}1 € / \mathrm{h} \\
30 € / \text { month }\end{array}$ \\
\hline & & & & & & \\
\hline Name & Specification & UdM & Type * & $\begin{array}{c}\text { Graph } \\
\text { Element }\end{array}$ & $\begin{array}{l}\text { Involved } \\
\text { Actors * }\end{array}$ & Example * \\
\hline \multirow{3}{*}{ Infrastructures } & Localization & Long/Lat & $\mathrm{C}$ & $\mathrm{L}$ & \multirow{3}{*}{$\mathrm{R}$} & Spatial coverage \\
\hline & Quantity & Length & C & $\mathrm{L}$ & & Physical extension \\
\hline & Features & Binary $(0 / 1)$ & $\mathrm{D}$ & $\mathrm{L} / \mathrm{N}$ & & Smart road \\
\hline \multirow[b]{2}{*}{ Intersection } & Localization & Long/Lat & $\mathrm{C}$ & $\mathrm{N}$ & \multirow{2}{*}{$\mathrm{U} / \mathrm{R}$} & Intersection location \\
\hline & Services & Binary $(0 / 1)$ & $\mathrm{D}$ & $\mathrm{N}$ & & Signalized/not Signalized \\
\hline Paths & Sequence of links & Binary $(0 / 1)$ & $\mathrm{D}$ & $\mathrm{L} / \mathrm{N}$ & $\mathrm{U} / \mathrm{R}$ & $\begin{array}{c}\text { Link sequence (between two } \\
\text { nodes) }\end{array}$ \\
\hline \multirow{2}{*}{ Routes } & Paths & Binary $(0 / 1)$ & $\mathrm{D}$ & $\mathrm{L}$ & \multirow{2}{*}{$\mathrm{U} / \mathrm{R}$} & Link sequence (between two \\
\hline & Sequence of paths & Binary $(0 / 1)$ & $\mathrm{D}$ & $\mathrm{L}$ & & $\begin{array}{l}\text { centroids) } \\
\text { Path sequence }\end{array}$ \\
\hline \multirow{3}{*}{ Zone } & Boundaries & Long/Lat & $\mathrm{C}$ & $\mathrm{N} / \mathrm{L}$ & \multirow{3}{*}{$\mathrm{U} / \mathrm{R}$} & Low Emission Zone \\
\hline & Authorized & Binary $(0 / 1)$ & $\mathrm{D}$ & $\mathrm{L}$ & & Low Emission Vehicles \\
\hline & Rates & $€ / \mathrm{h}$ & $\mathrm{C}$ & S & & $5 € / h$ \\
\hline \multirow{3}{*}{ Parking } & Localization & Long/Lat & $\mathrm{C}$ & $\mathrm{N}$ & \multirow{3}{*}{$\mathrm{U} / \mathrm{R}$} & Parking location \\
\hline & Services & Binary $(0 / 1)$ & $\mathrm{D}$ & $\mathrm{N}$ & & Recharge point \\
\hline & Price & $€ / h$ & $\mathrm{C}$ & $\mathrm{N}$ & & $1 € / h$ \\
\hline
\end{tabular}

* C: Continuous; D: Discrete; N: Nodes; L: Links; S: System; P: Performances; U: Users; R: Real operators.

\subsection{Objectives}

Table 5 reports the objectives' specification in relation to sustainability components and involved actors in the MaaS ecosystem. 
Table 5. Objectives expressed in relation to sustainability component and involved actors.

\begin{tabular}{|c|c|c|c|c|}
\hline \multirow{2}{*}{$\begin{array}{l}\text { Sustainability } \\
\text { Components }\end{array}$} & \multicolumn{4}{|c|}{ Involved Actors * } \\
\hline & MSPs & MO & MUs & $\mathrm{C} / \mathrm{SM}$ \\
\hline Economic & $\begin{array}{l}\text { Optimal use of } \\
\text { financial resources } \\
\text { (e.g., min transport } \\
\text { costs) }\end{array}$ & $\begin{array}{l}\text { Maximisation of } \\
\text { platform's user } \\
\text { (e.g., MaaS users) }\end{array}$ & $\begin{array}{c}\text { Maximum satisfaction } \\
\text { of mobility user needs } \\
\text { (e.g., user's } \\
\text { satisfaction) }\end{array}$ & $\begin{array}{l}\text { Optimal use of } \\
\text { economic resources } \\
\text { (e.g., public fund } \\
\text { for transport services) }\end{array}$ \\
\hline Social & $\begin{array}{c}\text { Risk minimisation } \\
\text { for workers } \\
\text { (e.g., worker accidents) }\end{array}$ & $\begin{array}{l}\text { Risk minimisation } \\
\text { for platform } \\
\text { (e.g., hacker attacks) }\end{array}$ & $\begin{array}{l}\text { Maximum satisfaction } \\
\text { of social user needs } \\
\text { (e.g., accessibility to } \\
\text { workplaces) }\end{array}$ & $\begin{array}{l}\text { Optimal use of social } \\
\text { resources (e.g., } \\
\text { accessibility } \\
\text { to health facilities) }\end{array}$ \\
\hline Environmental & - & - & $\begin{array}{l}\text { Maximum satisfaction } \\
\text { of environmental user } \\
\text { attitudes } \\
\text { (e.g., energy } \\
\text { consumptions) }\end{array}$ & $\begin{array}{l}\text { Optimal use of } \\
\text { environmental } \\
\text { resources } \\
\text { (e.g., energy for } \\
\text { transport) }\end{array}$ \\
\hline
\end{tabular}

* MO: MaaS Operator; MSPs: Mobility Service Provider; MUs: Users; C: Citizen; SM: system manager/planner.

\subsection{External and Technical Constraints}

Table 6 reports external and technical constraints' specification in relation to MaaS and transport system element.

Table 6. External and Internal (ET) constraints.

\begin{tabular}{|c|c|c|}
\hline Components & Description & $\begin{array}{c}\text { Example } \\
\text { (Unit of Measure) }\end{array}$ \\
\hline $\begin{array}{c}\text { External } \\
\text { constraints } \\
\left(\mathbf{y} \in \psi_{E T y}\right)\end{array}$ & $\begin{array}{l}\text { for nodes } \\
\text { for links } \\
\text { for route } \\
\text { for system }\end{array}$ & $\begin{array}{c}\text { Characteristics of recharge system (Volt) } \\
\text { Maximum speed limits }(\mathrm{km} / \mathrm{h}) \\
\text { Maximum route length }(\mathrm{km}) \text { or time }(\mathrm{h}) \\
\text { Allowed temporal windows (hh:mm } \\
\text {-hh:mm) }\end{array}$ \\
\hline $\begin{array}{c}\text { Internal } \\
\text { constraints } \\
\left(\mathbf{f} \in \psi_{E T f}\right)\end{array}$ & $\begin{array}{l}\text { for nodes } \\
\text { for links } \\
\text { for route } \\
\text { for system }\end{array}$ & $\begin{array}{c}\text { Maximum waiting time at stop (s) } \\
\text { Authorised vehicles in a road (e.g., only } \\
\text { EV) } \\
\text { Route capacity (veh/h) } \\
\text { Number of available vehicles (veh) }\end{array}$ \\
\hline
\end{tabular}

\subsection{Behavioral Constraints and Optimization Model}

As MaaS service design may be considered in the context of urban transport planning at tactical level, the design could be supported by a static simulation of the transport system. It represents and simulates the behavioural constraints. The designed variable is the sequence of nodes of the road network, that is an input of the problem, by considering an elastic demand respect to modal choice.

In the context of demand management, the dynamic simulation is useful to design a multimodal route-planner tool, that provides real-time information to users about alternative travel to be chosen.

The optimization model (16) cannot be solved with exact methods in real-size systems considering the current computation power and the available solution procedures. Some meta-heuristic methods have been proposed and compared to find the solution of optimization problem in transport field, as chon in [32]. The meta-heuristic procedures do not guarantee the convergence on the optimal solutions; they find sub-optimal solutions in a reasonable computation time. 


\subsection{Models for Supporting S-MaaS Policies}

The proposed modelling framework could support decision-makers in the definitions of policies in terms of control variables (Section 5.1), to pursue the objectives (Section 5.2) in the respect of the constrains (Sections 5.3 and 5.4).

The methods and models constitute the main element of DSS. The DSS requires data obtained by means of ICT for the design the MaaS services and for the definition of management and control strategies. DSS need to be used both for short-term forecasting and for medium and long-term planning. The mere use of the observed data (e.g., big data) without DSS is acceptable, when the transport system is configured and evolves in ordinary conditions. When new scenarios and services have to be designed and forecasted, DSS is necessary to support the design and plan (MaaS) services in a forecasted system configuration.

On the other hand, ICT is fundamental in a MaaS context because technologies operate as service supply integrator and is crucial in providing information to users and in support the system manager in designing sustainable services.

The integration between DSS and ICT constitute an Intelligent Transport System (ITS) that support decision makers in the specific case of designing and planning a S-MaaS.

\section{Conclusions}

MaaS is a recent concept that is spreading inside the transport sector, mainly due to a couple of general trends. The first is the general attitude towards ownership, that supported the birth and the evolution of the sharing economy and of the "as-a-service" approach. The second is the technological development and the availability of modern digital solutions.

Moreover, MaaS imposes to restructure the current mono-(or multi-)modal supply of transport services and to move towards new business models, with the creation of (virtual) mobility operators able integrate the services supplied by the single transport operators into a single service.

The paper presents the methods to be adopted for the design of an integrated transport service system. The consolidated design and assessment methodologies to support transportation planning, such as TSMs, NDP and VRP, have been extended in the context of the S-MaaS. In particular, the paper proposes a framework to support S-MaaS policies definition and implementation.

The core element of the proposed framework is an optimization model, based on the so-called "what-to" approach, which generates the best configuration to apply, design and manage the supply of transport services in order to reach the defined objectives. The inputs of the optimization model are the objectives connected to the three sustainability components: economic, social, environment, while the outputs are the optimal services for passengers, defined by the control or design variables. The model is subject to some constraints.

Objectives, control variables and constraints are specified for the MaaS context, in particular:

- the objectives are expressed in relation to each sustainability component (social, economic and environmental), and to the involved actors;

- the control variables and the constraints for the users are expressed for the collective services, individual services as passenger, and individual services as driver;

- the constraints are further classified in external (i.e., rules, laws) and internal (i.e., budget, vehicle type); the behavioural constrain (i.e., passengers, freight operators, manager choice) is expressed by means of the formalization the three components of the TSM: the supply model, the demand model, the assignment model.

The paper formalizes the general features of the proposed framework, that needs to be specified, calibrated and validated in the modelling components and applied in an experimental case studies. 
The proposed modelling framework contributes to support decision-makers to estimate potential effects produced by actions on transport system (e.g., services, pricing, incentives).

Future work will concern the following directions. The first concerns the specification and calibration of some modelling components in experimental MaaS case studies (e.g., MaaS vs. traditional transport services choice models, ... ). The second regards the integration of the proposed framework with ICT in order to incorporate Maas-oriented services inside a ITS environment. The third regards the experimentation of the proposed modelling framework in order to improve the knowledge and the practice about MaaS.

Author Contributions: Conceptualization, A.V.; methodology, A.V., G.M., C.R.; validation, G.M.; formal analysis, G.M.; investigation, C.R.; writing—original draft preparation, G.M.; writing—review and editing, C.R.; visualization, C.R.; supervision, A.V.. All authors have read and agreed to the published version of the manuscript.

Funding: This research is partially supported by the Dipartimento di ingegneria dell'Informazione, delle Infrastrutture e dell'Energia Sostenibile, Università Mediterranea di Reggio Calabria, and by the project "La Mobilità per i passeggeri come Servizio-MyPasS", Fondi PON R\&I 2014-2020 e FSC “Avviso per la presentazione di Progetti di Ricerca Industriale e Sviluppo Sperimentale nelle 12 aree di Specializzazione individuate dal PNR 2015-2020", codice identificativo ARS01_01100.

Institutional Review Board Statement: Not applicable.

Informed Consent Statement: Not applicable.

Data Availability Statement: Not applicable.

Conflicts of Interest: The authors declare no conflict of interest.

\section{References}

1. United Nations. Mobilizing Sustainable Transport for Development. Analysis and Policy Recommendations from the United Nations Secretary-General's High-Level Advisory Group on Sustainable Transport. Available online: https: / / sustainabledevelopment.un.org/index.php?page=view\&type=400\&nr=2375\&menu=35 (accessed on 9 February 2022).

2. United Nations. Sustainable Development Goals (SDGs). Available online: http://www.un.org/sustainabledevelopment/ sustainable-development-goals / (accessed on 9 February 2022).

3. Banister, D. The sustainable mobility paradigm. Transp. Policy 2008, 15, 73-80. [CrossRef]

4. Shibayama, T.; Emberger, G. New mobility services: Taxonomy, innovation and the role of ICTs. Transp. Policy 2020, 98, 79-90. [CrossRef]

5. Pantelidis, T.P.; Chow, J.Y.; Rasulkhani, S. A many-to-many assignment game and stable outcome algorithm to evaluate collaborative mobility-as-a-service platforms. Transp. Res. Part B Methodol. 2020, 140, 79-100. [CrossRef]

6. Kamargianni, M.; Li, W.; Matyas, M. A comprehensive review of "mobility as a service" systems. In Proceedings of the 95th Transportation Research Board Annual Meeting, Washington, DC, USA, 10-14 January 2016.

7. Chilà, G.; Musolino, G.; Polimeni, A.; Rindone, C.; Russo, F.; Vitetta, A. Transport models and intelligent transportation system to support urban evacuation planning process. IET Intell. Transp. Syst. 2016, 10, 279-286.

8. Nuzzolo, A.; Lam, W.H.K. (Eds.) Modelling Intelligent Multi-Modal Transit Systems, 1st ed.; CRC Press: Boca Raton, FL, USA, 2016.

9. Nuzzolo, A.; Comi, A. Advanced public transport and intelligent transport systems: New modelling challenges. Transportmetrica A Transp. Sci. 2016, 12, 674-699. [CrossRef]

10. Kamargianni, M.; Yfantis, L.; Muscat, J.; Azevedo, C.; Ben-Akiva, M. Incorporating the Mobility as a Service Concept Into Transport Modelling and Simulation Frameworks; MaaSLab Working Paper Series Paper No. 18-05; MaaSLab: London, UK, 2018.

11. ERTICO. Mobility as a Service (MaaS) and Sustainable Urban Mobility Planning. ITS Europe (Editor). Available online: https: / / www.eltis.org/sites/default/files/mobility_as_a_service_maas_and_sustainable_urban_mobility_planning.pdf (accessed on 9 February 2022).

12. Hietanen, S. "Mobility as a service"-The new transport model? Eurotransport 2014, 12, 2-4.

13. Jittrapirom, P.; Caiati, V.; Feneri, A.M.; Ebrahimigharehbaghi, S.; Alonso-González, M.J.; Narayan, J. Mobility as a service: A critical review of definitions, assessments of schemes, and key challenges. Urban Plan. 2017, 2, 13-25. [CrossRef]

14. Holmberg, P.-E.; Collado, M.; Sarasini, S.; Williander, M. Mobility as a Service-MaaS. Describing the Framework (Final Report MaaS Framework); Viktoria Swedish ICT: Gothenburg, Sweden, 2016.

15. Atkins. Journeys of the Future. Introducing Mobility as a Service. Available online: https://exploreconsulting.careers/uploads/ Atkins-Journeys-of-the-future_300315.pdf (accessed on 9 February 2022). 
16. Atasoy, B.; Ikeda, T.; Song, X.; Ben-Akiva, M.E. The concept and impact analysis of a flexible mobility on demand system. Transp. Res. Part C Emerg. Technol. 2015, 56, 373-392. [CrossRef]

17. CIVITAS. Mobility-as-a-Service: A New Transport Model. Available online: https://civitas.eu/sites/default/files/civitas_ insight_18_mobility-as-a-service_a_new_transport_model.pdf (accessed on 9 February 2022).

18. Smith, G.; Hensher, D.A. Towards a framework for mobility-as-a-service policies. Transp. Policy 2020, 89, 54-65. [CrossRef]

19. Nemtanu, F.; Schlingensiepen, J.; Buretea, D.; Iordache, V. Mobility as a service in smart cities. In Responsible EntrepreneurshipVision, Development and Ethics, Proceedings of the 9th International Conference for Entrepreneurship, Innovation and Regional Development, Bucharest, Romania, 23-24 June 2016; Zbuchea, A., Nikolaidis, D., Eds.; Comunicare.ro: Bucharest, Romania, 2016 ; pp. $425-435$.

20. Giesecke, R.; Surakka, T.; Hakonen, M. Conceptualising Mobility as a service. A user centric view on key issues of mobility services. In Proceedings of the 11th International Conference on Ecological Vehicles and Renewable Energies (EVER), Monte Carlo, Monaco, 6-8 April 2016.

21. König, D.; Eckhardt, J.; Aapaoja, A.; Sochor, J.; Karlsson, M. Business and Operator Models for Mobility as a Service (MaaS) (Deliverable 3 to the MAASiFiE Project); Centre for Effective Dispute Resolution: Brussels, Belgium, 2016.

22. Wang, X.; Yan, X.; Zhao, X.; Cao, Z. Identifying latent shared mobility preference segments in low-income communities: Ride-hailing, fixed-route bus, and mobility-on-demand transit. Travel Behav. Soc. 2021, 26, 134-142. [CrossRef]

23. Song, Y.; Li, D.; Cao, Q.; Yang, M.; Ren, G. The whole day path planning problem incorporating mode chains modeling in the era of mobility as a service. Transp. Res. Part C Emerg. Technol. 2021, 132, 103360. [CrossRef]

24. Ortuzar, J.; Willumsen, L.G. Modelling Transport, 3rd ed.; John and Wiley and Sons: Hoboken, NJ, USA, 2001.

25. Cascetta, E. Transportation Systems Analysis. Models and Applications; Springer: New York, NY, USA, 2009.

26. Azevedo, C.L.; Seshadri, R.; Gao, S.; Atasoy, B.; Akkinepally, A.P.; Christofa, E.; Ben-Akiva, M. Tripod: Sustainable travel incentives with prediction, optimization, and personalization. In Proceedings of the Transportation Research Board 97th Annual Meeting, Washington, DC, USA, 7-11 January 2018.

27. Ho, C.Q.; Mulley, C.; Hensher, D.A. Public preferences for mobility as a service: Insights from stated preference surveys. Transp. Res. Part A 2020, 131, 70-90. [CrossRef]

28. Billheimer, J.W.; Gray, P. Network design with fixed and variable cost elements. Transp. Sci. 1973, 7, 49-74. [CrossRef]

29. Chen, M.; Alfa, A.S. A Network design algorithm using a stochastic incremental traffic assignment approach. Transp. Sci. 1991, 25, 215-224. [CrossRef]

30. Zhou, Y.; Cao, C.; Feng, Z. Optimization of multimodal discrete network design problems based on super networks. Appl. Sci. 2021, 11, 10143. [CrossRef]

31. Cantarella, G.E.; Pavone, G.; Vitetta, A. Heuristics for urban road network design: Lane layout and signal settings. Eur. J. Oper. Res. 2006, 175, 1682-1695. [CrossRef]

32. Cantarella, G.E.; Vitetta, A. The multi-criteria road network design problem in an urban area. Transportation 2006, 33, 357-588. [CrossRef]

33. Webster, F.V. Traffic Signal Settings; Road Research Technical Paper No. 39; Road Research Laboratory: London, UK, 1958.

34. Allsop, R.E. SIGSET: A computer program for calculating traffic capacity of signal controlled road junctions. Traffic Eng. Control $1971,12,58-60$.

35. Allsop, R.E. Some possibilities for using traffic control to influence trip destinations and route choice. In Proceedings of the 6th International Symposium on Transportation and Traffic Theory, Amsterdam, The Netherlands, 26-28 August 1974; pp. 345-374.

36. Cantarella, G.E.; Improta, G.; Sforza, A. Road network signal setting: Equilibrium conditions. In Concise Encyclopaedia of Traffic and Transportation Systems; Papageorgiou, M., Ed.; Pergamon Press: Oxford, UK, 1991; pp. 366-371.

37. Little, J.D.C. The synchronisation of traffic signals by mixed-integer-linear-programming. Oper. Res. 1966, 14, 568-594. [CrossRef]

38. Robertson, D.I. TRANSYT method for area traffic control. Traffic Eng. Control 1969, 10, $276-281$.

39. Gartner, N.H. Area traffic control and network equilibrium. In Traffic Equilibrium Methods, Lecture Notes in Economics and Mathematical Systems; Florian, M., Ed.; Springer: Berlin/Heidelberg, Germany, 1976; Volume 118, pp. $274-297$.

40. Smith, M.J. The existence, uniqueness and stability of traffic equilibria. Transp. Res. B 1979, 13, 295-304. [CrossRef]

41. Ceylan, H.; Bell, M.G.H. Traffic signal timing optimization based on genetic algorithm approach, including driver's routing. Transp. Res. B 2004, 38, 329-342. [CrossRef]

42. Russo, F.; Vitetta, A. A topological method to choose optimal solutions after solving the multi-criteria urban road network design problem. Transportation 2006, 33, 347-370. [CrossRef]

43. Russo, F. Transit frequencies design for enhancing the efficiency of public urban transportation systems: An optimization model and an algorithm. In Logistics Management and Environmental Aspects. Intelligent Transportation and Telemetric Systems. Marketing, Vehicle Finance and Leasing; International Symposium on Automotive Technology and Automation: Dusseldorf, Germany, 1998.

44. Guihaireab, V.; Hao, J.-K. Transit network design and scheduling: A global review. Transp. Res. Part A Policy Pract. 2008, 42, 1251-1273. [CrossRef]

45. Bourbonnais, P.-L.; Morency, C.; Trépanier, M.; Martel-Poliquin, É. Transit network design using a genetic algorithm with integrated road network and disaggregated O-D demand data. Transportation 2021, 48, 95-130. [CrossRef]

46. Huang, D.; Liu, Z.; Fu, X.; Blythe, P.T. Multimodal transit network design in a hub-and-spoke network framework. Transp. A Transp. Sci. 2018, 14, 706-735. [CrossRef]

47. Laporte, G. What you should know about the vehicle routing problem. Nav. Res. Logist. 2007, 54, 811-819. [CrossRef] 
48. Laporte, G. Fifty years of vehicle routing. Transp. Sci. 2009, 43, 408-416. [CrossRef]

49. Gendreau, M.; Potvin, J.Y.; Bräysy, O.; Hasle, G.; Løkketamgen, A. Metaheuristics for the vehicle routing problem and its extensions: A categorized bibliography. In The Vehicle Routing Problem: Latest Advances and New Challenges (143-169); Golden, B., Raghavan, S., Wasil, E., Eds.; Springer: Berlin/Heidelberg, Germany, 2008.

50. Fisher, M.L. Optimal solution of vehicle routing problems using minimum K-trees. Oper. Res. 1994, 42, 626-642. [CrossRef]

51. Kallehauge, B.; Larsen, J.; Madsen, O.B.G. Lagrangian duality applied to the vehicle routing problem with time windows. Comput. Oper. Res. 2006, 33, 1464-1487. [CrossRef]

52. Chabrier, A. Vehicle routing problem with elementary shortest path based column generation. Comput. Oper. Res. 2006, 33, 2972-2990. [CrossRef]

53. Choi, E.; Tchab, D.W. A column generation approach to the heterogeneous fleet vehicle routing problem. Comput. Oper. Res. 2007, 34, 2080-2095. [CrossRef]

54. Azi, N.; Gendreau, M.; Potvin, J.-Y. An exact algorithm for a single-vehicle routing problem with time windows and multiple routes. Eur. J. Oper. Res. 2007, 178, 755-766. [CrossRef]

55. Baker, B.M.; Ayechew, M.A. A genetic algorithm for the vehicle routing problem. Comput. Oper. Res. 2003, 30, 787-800. [CrossRef]

56. Berger, J.; Barkaoui, M. A parallel hybrid genetic algorithm for the vehicle routing problem with time windows. Comput. Oper. Res. 2004, 31, 2037-2053. [CrossRef]

57. Gribkovskaia, I.; Laporte, G.; Shyshou, A. The single vehicle routing problem with deliveries and selective pickups. Comput. Oper. Res. 2008, 35, 2908-2924. [CrossRef]

58. Brandão, J. A deterministic tabu search algorithm for the fleet size and mix vehicle routing problem. Eur. J. Oper. Res. 2009, 195, 716-728. [CrossRef]

59. Osman, I.H. Metastrategy simulated annealing and tabu search algorithms for the vehicle routing problem. Ann. Oper. Res. 1993, 41, 421-451. [CrossRef]

60. Tavakkoli-Moghaddam, R.; Safaei, N.; Gholipour, Y. A hybrid simulated annealing for capacitated vehicle routing problems with the independent route length. Appl. Math. Comput. 2006, 176, 445-454. [CrossRef]

61. Lin, C.; Choy, K.; Ho, G.; Chung, S.; Lam, H. Survey of green vehicle routing problem: Past and future trends. Expert Syst. Appl. 2013, 41, 1118-1138. [CrossRef]

62. Keskin, M.; Çatay, B. Partial recharge strategies for the electric vehicle routing problem with time windows. Transp. Res. Part C Emerg. Technol. 2016, 65, 111-127. [CrossRef]

63. Hiermann, G.; Puchinger, J.; Ropke, S.; Hartl, R.F. The electric fleet size and mix vehicle routing problem with time windows and recharging stations. Eur. J. Oper. Res. 2016, 252, 995-1018. [CrossRef]

64. Lin, J.; Zhou, W.; Wolfson, O. Electric vehicle routing problem. Transp. Res. Procedia 2016, 12, 508-521. [CrossRef]

65. Musolino, G.; Rindone, C.; Polimeni, A.; Vitetta, A. Planning urban distribution center location with variable restocking demand scenarios: General methodology and testing in a medium-size town. Transp. Policy 2018, 80, 157-166. [CrossRef]

66. Cascetta, E.; Cantarella, G.E. A day-to-day and within-day dynamic stochastic assignment model. Transportation 1991, 25, $277-291$. [CrossRef] 